\title{
Ginger Extract as Green Corrosion Inhibitor for Steel in Sulfide Polluted Salt Water
}

\author{
Abd El-Aziz S. Fouda*, Ahmed Abdel Nazeer ${ }^{\dagger}$, Mohamed Ibrahim ${ }^{\ddagger}$, and Mohamed Fakih ${ }^{\star}$ \\ Department of Chemistry, Faculty of Science, El-Mansoura University, El-Mansoura-35516, Egypt. \\ ${ }^{*}$ E-mail:_asfouda@mans.edu.eg \\ ${ }^{\dagger}$ National Research Center, Electrochemistry and Corrosion Lab., Dokki, Cairo, Egypt \\ Water and waste water company, Dakahlia, Egypt \\ (Received January 7, 2013; Accepted February 26, 2013)
}

\begin{abstract}
Extract of ginger has been evaluated as a green inhibitor for the corrosion of steel in sulfide polluted $\mathrm{NaCl}$ solution using potentiodynamic polarization, electrochemical impedance spectroscopy (EIS) and electrochemical frequency modulation (EFM) techniques. Potentiodynamic polarization measurements showed that this extract acts as a mixed type inhibitor but mainly inhibits the cathodic reaction. The inhibition efficiency was found to increase with inhibitor concentration reaching to approximately $83.9 \%$ using $250 \mathrm{ppm}$ of ginger. Nyquist plots show a single capacitive loop in uninhibited and inhibited solutions. From EFM the causality factors are very close to theoretical values which indicate that the measured data are of good quality. The adsorption process of the studied extract on steel surface obeys Temkin adsorption isotherm. The results obtained from the different electrochemical techniques were in good agreement which prove the validity of these tools in measurement of corrosion rate. Ginger extract has no effect on Escherichia Coli and can be applied safely on waste water treatment plants.
\end{abstract}

Key words: Corrosion inhibition, Steel, $\mathrm{NaCl}, \mathrm{Na}_{2} \mathrm{~S}$, Green inhibitor (ginger)

\section{INTRODUCTION}

Corrosion is the deterioration of metal by chemical attack or reaction with its environment. It is a constant and continuous problem, often difficult to eliminate completely. Prevention would be more practical and achievable than complete elimination. Regarding the chemical structure and chemical behavior, an inorganic compound must be able to oxidize the metal, forming a passive layer on its surface. On the other hand, a molecule of an organic compound must have some features that give it the ability to act as a corrosion inhibitor. Among these, the molecule may have a large structure, double bonds, an active center or group, etc. These features give the molecule the ability to cover a large area of a metal surface with a firmly attached film. ${ }^{1}$

Apart from the structural aspects, there are also economic and environmental considerations. Thus, since the whole subject of corrosion is about its destructive economical effect, the used inhibitor must be cheap. Furthermore, due to the recent increasing awareness of green chemistry, it must be a nontoxic and environmentally friendly chemical. One of the sources of these cheap and clean inhibitors is plants. Green corrosion inhibitors are biodegradable and do not contain heavy metals or other toxic compounds. Some research groups have reported the successful use of naturally occurring substances to inhibit the corrosion of metals in acidic and alkaline environment. Several reports are available on the various natural products used as green inhibitors. Low-grade gram flour, natural honey, onion, potato, gelatin, plant roots, leaves, seeds, and flowers gums have been reported as good inhibitors. However, most of them have been tested on steel and nickel sheets. Although some studies have been performed on aluminum sheets, the corrosion effect is seen in very mild acidic or basic solutions (mill molar solutions). Many recent researches ${ }^{2-9}$ have adopted this trend and carried out their work on naturally occurring substances. Promising results were obtained in previous work in this field. It was reported that Khillah extract inhibits steel corrosion in $\mathrm{HCl}$ solution with inhibition efficiency as high as $99 \%,{ }^{2}$ while opuntia extract inhibits the corrosion of aluminum in the same acid with efficiency of about $96 \% .{ }^{9}$

The aim of this work is to study: i) The effect of ginger extract as green corrosion inhibitor for the steel in sulfide polluted salt water using potentiodynamic polarization, electrochemical impedance spectroscopy (EIS) and electrochemical frequency modulation (EFM) techniques and ii) its biological effect on the activity of Escherichia Coli. 


\section{EXPERIMENTAL}

\section{Materials and Methods}

The material used is steel which was provided from a bridge in a Talkha sanitation plant, Egypt. These samples have the following chemical composition (wt $\%$ ): $0.005 \%$ $\mathrm{Si}, 0.248 \% \mathrm{Mn}, 1.832 \% \mathrm{Zn}$ and the remainder is iron. For electrochemical measurements, the sheets were welded with $\mathrm{Cu}$-wire for electrical connection and mounted into glass tubes of appropriate diameter using Araldite to offer an active surface of $\left(1 \mathrm{~cm}^{2}\right)$ geometric area to contact the test solution. Prior to each experiment, these sheets were abraded with 800-1200 emery paper, washed with bi-distilled water, degreased with absolute ethanol and then dried. A conventional electrochemical cell of capacity $100 \mathrm{ml}$ was used containing three compartments for working, platinum spiral counter and saturated calomel electrode (SCE) as reference electrode. The measurements were carried out in aerated non-stirred $3.5 \% \mathrm{NaCl}$ with $16 \mathrm{ppm}$ sulfide in the presence of various concentrations of the investigated compound, as environmentally-friendly corrosion inhibitor. All solutions were freshly prepared from analytical grade chemical reagents using bi-distilled water and were used without further purification. For each run, a freshly prepared solution as well as a cleaned set of electrodes was used. Each run was carried out in aerated stagnant solutions at the required temperature using a water thermostat. All experiments were carried out at $25 \pm 1{ }^{\circ} \mathrm{C}$ using circulator thermostat and solutions were not deaerated. The potentiodynamic polarization curves were carried out at a scan rate of $1 \mathrm{mV} \mathrm{s}^{-1}$ starting from $-1.7 \mathrm{~V}$ up to $-0.1 \mathrm{~V}$ (SCE). Before polarization, the open circuit potential of the working electrode was measured as a function of time during 30 $\mathrm{min}$, the time necessary to reach a quasi-stationary value for the open-circuit potential. Impedance measurements were carried out using AC signals of amplitude $5 \mathrm{mV}$ peak to peak at the open-circuit potential in the frequency range $100 \mathrm{kHz}$ and $0.2 \mathrm{~Hz}$. All impedance measurements were recorded at open circuit potential (OCP) after immersion the electrode for 30 minutes in the test solution. All electrochemical measurements were performed with Potentiostat / Galvanostat / Zra analyzer (Gamry PCI300/4). A personal computer with DC 105 software for polarization, EFM140 software for electrochemical frequency modulation and EIS300 software for EIS measurements and Echem Analyst 5.21 was used for data fitting and calculating.

\section{Preparation of Plant Extracts}

The present investigation was carried out using the plant namely ginger. The uses parts were the bark and the rhizomes of ginger. The sample were purchased from the local market and ground into a fine powder to give $500 \mathrm{~g}$ of powdered materials which extracted separately by soaking at room temperature for six times with methanol $(5 \mathrm{~L})$, then the methanolic extract of the sample was concentrated to nearly dryness under reduced pressure by using the rotary evaporator at $45^{\circ} \mathrm{C}$ to achieve the crude methanolic extract which kept for further investigation.

\section{Botanical aspect of ginger: \\ English name: ginger \\ Botanical name: Zingiber officinale \\ Family: Zingiberaceae}

\section{Chemical structures of ginger:}

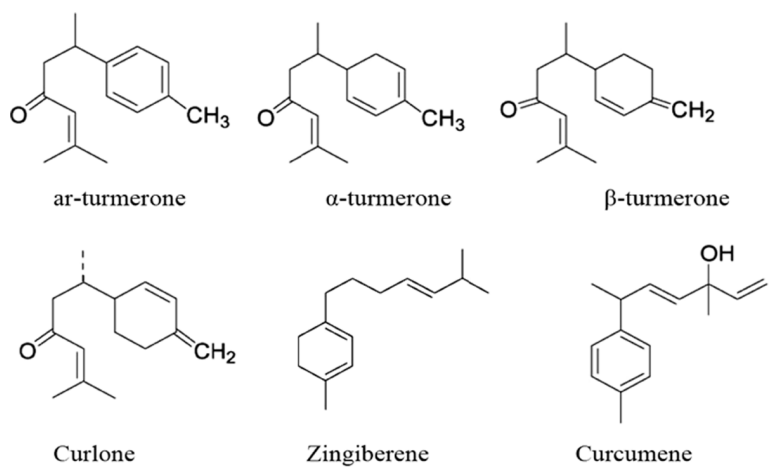<smiles>CCCCCC(O)CC(=O)CCc1ccc(O)c(OC)c1</smiles>

gingerol

\section{Preparation of Bacterial Agriculture Media}

Suspend 50 grams of the medium in one liter of bi-distilled water and dissolve it by heating. Sterilize in autoclave at $121^{\circ} \mathrm{C}$ for $15 \mathrm{~min}$. Cool to $45-50^{\circ} \mathrm{C}$, mix well and dispense into plates. Allow the plates to solidify. The prepared medium should be stored at $8-15^{\circ} \mathrm{C}$. The color is violet-red

\section{RESULTS AND DISCUSSION}

\section{Potentiodynamic Polarization Measurements}

Fig. 1 shows the potentiodynamic polarization curves of steel in sulfide polluted salt water without and with different concentrations of ginger extract at $25^{\circ} \mathrm{C}$. The obtained electrochemical parameters; cathodic and anodic Tafel slopes $\left(\beta_{c}\right.$ and $\left.\beta_{a}\right)$ respectively, open circuit potential $\left(E_{O C}\right)$, cor- 


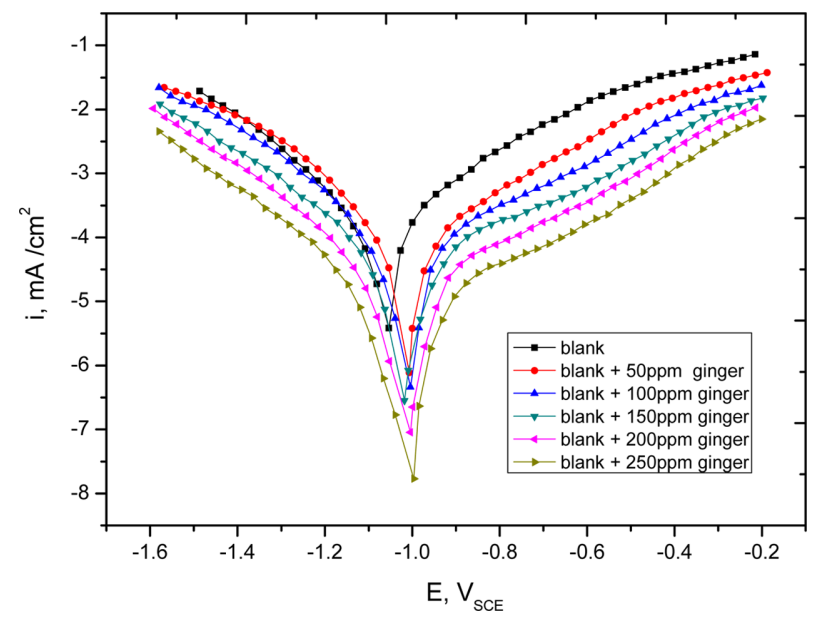

Fig. 1. Potentiodynamic polarization curves for the corrosion of steel in $3.5 \% \mathrm{NaCl}+16 \mathrm{ppm} \mathrm{Na} 2 \mathrm{~S}$ in the absence and presence of different concentrations of ginger at $25^{\circ} \mathrm{C}$.

rosion potential $\left(E_{\text {corr }}\right)$, corrosion current density $\left(i_{\text {corr }}\right)$ : and corrosion rate (C.R.). were obtained and listed in Table 1. The percentage of inhibition efficiency, I\% and the degree of surface coverage $(\theta)$ (Table 1) at each concentration was calculated using the equation: $:^{10,11}$

$$
\% \mathrm{I}=100\left[1-i_{\text {corr }(\text { inh })}-i_{\text {corr }}\right]
$$

where $i_{c o r r}$ and $i_{\text {corr }(i n h)}$ are the corrosion current densities of uninhibited and inhibited solutions, respectively.

An inspection of the results obtained from Table 1 reveals that, the presence of different concentrations of the additive compound reduce the anodic and cathodic current densities by decreasing the hydrogen evolution and the metal dissolution at the cathode which appears from the table that $\beta_{c}>\beta_{a}$ this is due to presence of donor atom having a lone pair of electrons attached with the surface by charge or electron transfer between the inhibitor and the metal surface also the bulky group of the inhibitor makes strike hindrance at the metal surface for the reach of the corrosive medium to the metal surface and the suppression in current increases as the inhibitor concentration

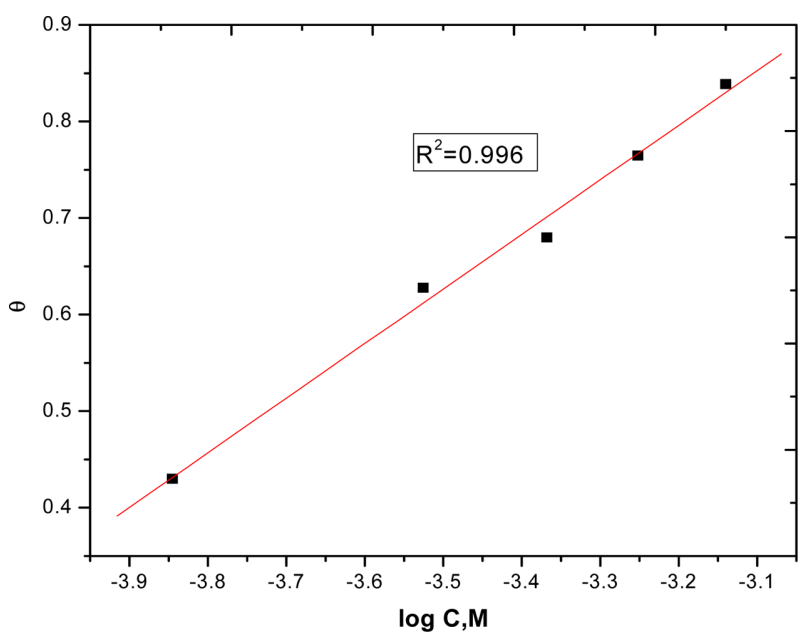

Fig. 2. Temkin adsorption isotherm plotted as $\theta$ vs. $\log C$ of ginger for the corrosion of steel in sulfide polluted salt water.

increases, this indicate the inhibiting effects of the investigated compound. The slight shifts of $E_{\text {corr }}$ values towards less negative direction are found in the presence of various concentrations of this compound in sulfide polluted salt water. Generally, increase in inhibitor concentration shifts corrosion potential to less negative values. This can be explained by a small domination of the anodic reaction inhibition. ${ }^{12}$ The $\%$ I was found to increase with increasing the inhibitor concentration.

\section{Adsorption isotherm:}

One of the most convenient ways of expressing adsorption quantitatively is by deriving the adsorption isotherm that characterizes the metal/inhibitor/environment system. ${ }^{13}$ The values of the degree of surface coverage $\theta$ were evaluated at different concentrations of the inhibitor in sulfide polluted salt water. Attempts were made to fit $\theta$ values to various adsorption isotherms. The Temkin adsorption isotherm fits the experimental data. A plot of $\theta$ against $\log \mathrm{C}$ for all concentrations of inhibitor is shown in Fig. 2 gives a straight line relationship in all cases which suggests that the adsorption of the studied inhibitor on the

Table 1. The effect of concentration of ginger on the electrochemical parameters calculated by using potentiodynamic technique for corrosion of steel in sulfide polluted salt water at $25^{\circ} \mathrm{C}$

\begin{tabular}{cccccccc}
\hline Conc., $\mathrm{ppm}$ & $-E_{\text {corr }, \mathrm{V}}$ & $i_{\text {corr }}, \mu \mathrm{A} \mathrm{cm}^{-2}$ & $-\beta_{c}, \mathrm{mV} \mathrm{dec}^{-1}$ & $\beta_{a}, \mathrm{mV} \mathrm{dec}^{-1}$ & $\mathrm{C} . \mathrm{R} \mathrm{mmy}^{-1}$ & $\theta$ & $\mathrm{I} \%$ \\
\hline Blank & 1.056 & 11470 & 265 & 209 & 133.19 & - & - \\
50 & 1.077 & 6538 & 253 & 196 & 99.11 & 0.430 & 43.0 \\
100 & 1.063 & 4269 & 242 & 166 & 53.24 & 0.628 & 62.8 \\
150 & 1.083 & 3670 & 221 & 147 & 35.76 & 0.680 & 68.0 \\
200 & 1.080 & 2909 & 220 & 144 & 33.77 & 0.746 & 74.6 \\
250 & 1.058 & 1858 & 193 & 124 & 19.11 & 0.839 & 83.9 \\
\hline
\end{tabular}


Table 2. The equilibrium constant of the adsorption process $\left(K_{a d s}\right)$, free energy of binding $\left(\Delta G^{o}\right.$ ads $)$ and the interaction parameter (a) of the investigated compound at $25^{\circ} \mathrm{C}$

\begin{tabular}{ccc}
\hline $\mathrm{a}$ & $K_{a d s}, \mathrm{M}^{-1}$ & $-\Delta G_{a d s,}^{o} \mathrm{~kJ} \mathrm{~mol}^{-1}$ \\
\hline 11.2 & $1.8 \times 10^{8}$ & 35.63 \\
\hline
\end{tabular}

steel surface follow Temkin adsorption isotherm. The strong correlation $\left(R^{2}=0.996\right)$ for the Temkin adsorption isotherm plot confirmed the validity of this approach.

$$
K_{a d s} C=\exp (-2 \mathrm{a} \theta)
$$

where a is molecular interaction parameter, $\theta$ is the degree of surface coverage, $K_{a d s}$ is the equilibrium constant of adsorption process and $\mathrm{C}$ is the inhibitor concentration. It is well known that the equilibrium constant of adsorption $\left(K_{a d s}\right)$ is related to the standard adsorption free energy ( $\Delta G^{o}$ ads) and can be calculated by the following equation: ${ }^{14}$

$$
K_{a d s}=1 / 55.5 \exp \left[-\Delta G^{o}{ }_{a d s} / R T\right]
$$

Table 2 shows the calculated values of molecular interaction a, equilibrium constant of adsorption process, $K_{a d s}$ and free energy $\left(\Delta G_{a d s}^{o}\right)$ obtained from Temkin plot. The value of a are positive shows that attraction exists in adsorption layer. ${ }^{15}$ The relatively high and negative free energy values may indicate a relatively strong and spontaneous adsorption of the investigated compound on the metal surface, which explains its high corrosion inhibition efficiency. A value of $-40 \mathrm{~kJ} \mathrm{~mol}^{-1}$ is usually adopted as a threshold value between chemical and physical adsorption. ${ }^{16}$ The calculated values of $\Delta G_{a d s}^{o}$, for the investigated compound with the metal surface is $-35.63 \mathrm{~kJ} \mathrm{~mol}^{-1}$, which means that the inhibitor is physically adsorbed

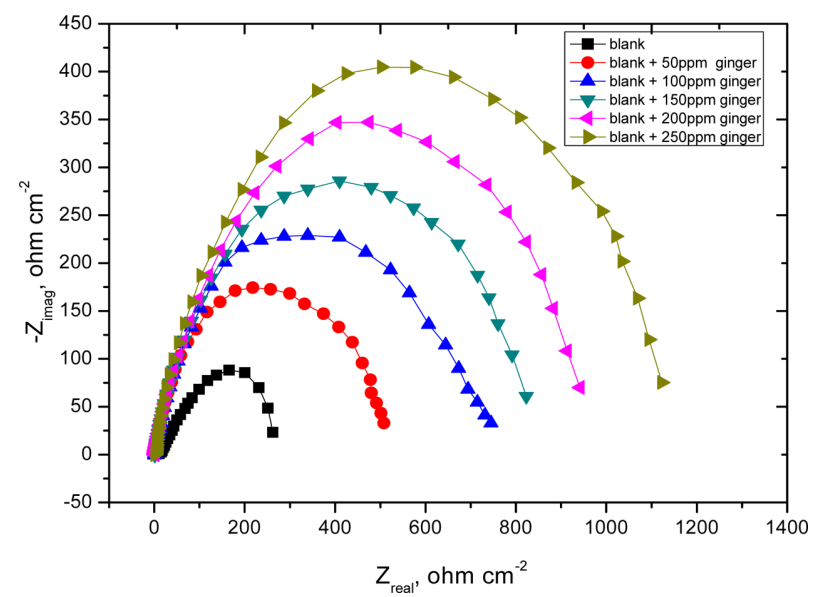

Fig. 3. Nyquist plots recorded for steel in $3.5 \% \mathrm{NaCl}+16 \mathrm{ppm}$ $\mathrm{Na}_{2} \mathrm{~S}$ with and without different concentrations of ginger at $25^{\circ} \mathrm{C}$.

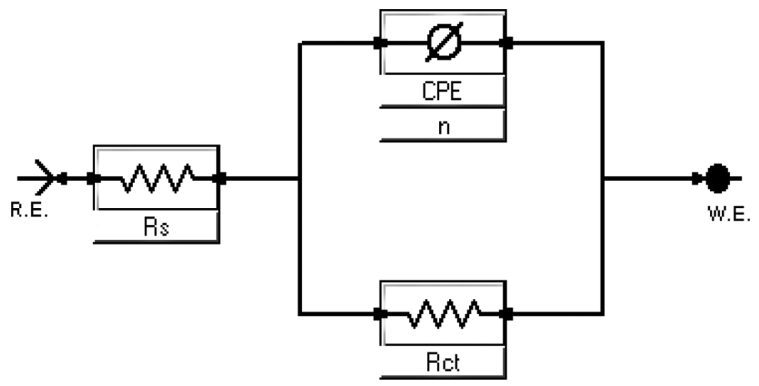

Fig. 4. Electrical equivalent circuit used to fit the impedance spectra.

through electrostatic interaction.

\section{Electrochemical Impedance Spectroscopy (EIS)}

Fig. 3 shows the Nyquist plot of steel in $3.5 \% \mathrm{NaCl}$ and $16 \mathrm{ppm} \mathrm{Na}_{2} \mathrm{~S}$ in absence and presence of different concentrations of investigated compound was investigated by EIS method at $25^{\circ} \mathrm{C}$ after $20 \mathrm{~min}$ immersion. All the impedance spectra were measured at the corresponding open-circuit potentials. It is apparent that Nyquist plots show a single capacitive loop, both in uninhibited and inhibited solutions. The data described a semicircle at low frequencies, indicating that the corrosion process was now under adsorption control, through an inhibitor-formed film, whereas at low frequencies a depressed, capacitive-like semicircle was observed, which correspond to a charge transfer-controlled corrosion process. According to Ramachandran, ${ }^{15}$ the film formed in the presence of ginger extract acts as a protective barrier against aggressive ions from the bulk solution. Thus, the corrosion process in the presence of the inhibitor was under diffusion and charge transfer mixed mechanism. The EIS data were simulated using equivalent electric circuits as shown in Fig. 4 where $R_{S}$ represents the solution or electrolyte resistance, $C_{d l}$ the double layer capacitance, $R_{c t}$ the charge transfer resistance.

Form the Nyquist plot it is obvious that low frequency data are on the right side of the plot and higher frequencies are on the left. This is true for EIS data where impedance usually falls as frequency rises (this is not true of all circuits). The capacity of double layer $C_{d l}$ can be calculated from the following equation:

$$
C_{d l}=\frac{1}{2 \pi f_{\max } R_{c t}}
$$

where $f_{\max }$ is maximum frequency. The parameters obtained from impedance measurements are given in Table 3. It can see from Table 3 that the values of charge transfer resistance increase with inhibitor concentration. ${ }^{17}$ In the case 
Table 3. Electrochemical kinetic parameters obtained by EIS technique for the corrosion of steel in $3.5 \% \mathrm{NaCl}+16 \mathrm{ppm} \mathrm{Na}_{2} \mathrm{~S}$ alone and with different concentrations of ginger at $25^{\circ} \mathrm{C}$

\begin{tabular}{|c|c|c|c|c|c|c|}
\hline Conc., $\mathrm{M}$ & $\mathrm{R}_{\mathrm{s}} \Omega \mathrm{cm}^{2}$ & $\mathrm{C}_{d l}, \mu \mathrm{F} \mathrm{cm}^{-2}$ & $\mathrm{n}$ & $R_{c t} \Omega \mathrm{cm}^{2}$ & $\theta$ & $\%$ I \\
\hline blank & 1.294 & 605.5 & 0.886 & 3.863 & - & - \\
\hline 50 & 1.194 & 433.0 & 0.878 & 4.782 & 0.192 & 19.2 \\
\hline 100 & 1.181 & 392.1 & 0.886 & 10.24 & 0.623 & 62.3 \\
\hline 150 & 1.132 & 367.1 & 0.878 & 11.68 & 0.669 & 66.9 \\
\hline 200 & 1.122 & 356.0 & 0.861 & 14.87 & 0.740 & 74.0 \\
\hline 250 & 1.110 & 333.6 & 0.848 & 25.49 & 0.848 & 84.8 \\
\hline
\end{tabular}

of impedance studies, \% I increases with inhibitor concentration in the presence of investigated inhibitors. The impedance study confirms the inhibiting characters of these compounds obtained with potentiodynamic polarization methods. It is also noted that the $C_{d l}$ values tend to decrease when the concentration of these compounds increases. This decrease in $C_{d l}$, which can result from a decrease in local dielectric constant and/or an increase in the thickness of the electrical double layer, suggests that these compounds molecules function by adsorption at the metal/solution interface. ${ }^{18}$

EIS data Table 3 shows that the $R_{c t}$ values increase and the $C_{d l}$ values decrease with increasing the inhibitor concentrations. This is due to the gradual replacement of water molecules by the adsorption of the inhibitor molecules on the metal surface, decreasing the extent of dissolution reaction. The high $R_{c t}$ values, are generally associated with slower corroding system. ${ }^{19,20}$ The decrease in the $C_{d l}$ can result from the decrease of the local dielectric constant and/or from the increase of thickness of the electrical double layer, ${ }^{21}$ suggested that the inhibitor molecules function by adsorption at the metal/solution interface.

The inhibiting effect of this compound can be attributed to their parallel adsorption at the metal solution interface. The parallel adsorption is owing to the presence of one or more active center for adsorption. The chemisorptions take place by the formation of a chemical bond between the metal and the adsorbed molecule. Chemisorptions involve charge or charge transfer from inhibitor molecule to the metal surface forming co-ordinate type bond. ${ }^{22}$

\section{Electrochemical Frequency Modulation (EFM)}

Intermodulation spectra obtained from EFM measurements are presented in Fig. 5 as examples of steel in 3.5\% $\mathrm{NaCl}+16$ ppm $\mathrm{Na}_{2} \mathrm{~S}$ containing different concentrations of ginger at $25^{\circ} \mathrm{C}$. Each spectrum is a current response as a function of frequency. The calculated corrosion kinetic parameters in the presence of $3.5 \% \mathrm{NaCl}+16 \mathrm{ppm} \mathrm{Na}_{2} \mathrm{~S}$ alone and with different concentrations of the investi- gated inhibitor at $25^{\circ} \mathrm{C}\left(i_{c o r r}, \beta_{a}, \beta_{c}, \mathrm{CF}-2\right.$ and $\left.\mathrm{CF}-3\right)$ are given in Table 4. From this Table it is obvious that the corrosion current densities decrease by increasing the concentration of inhibitor and hence the inhibition efficiency increases. Also it is clear that the causality factors are very close to theoretical values which according to EFM theory should guarantee the validity of Tafel slope and corrosion current densities. In addition the values of causality factors indicate that the measured data are of good quality. ${ }^{23}$ The obtained results showed good agreement of inhibition efficiency obtained from the potentiodynamic polarization, EIS and EFM methods.

\section{Biological Effect of Ginger on Escherichia Coli}

After the bacterial agriculture of Escherichia Coli in the presence and absence of the inhibitor we found a little effect on the bacterial activity of Escherichia Coli according to Table 5 and Fig. 6. Ginger is suggested that it has oxygen donor atoms attached with the proteins and lipids on the bacterial tissues surface making a little activity for it. So we found that this inhibitor has no toxicity on the bacterial activity, and can be applied on the waste water plants safely without any problems in treating waste water operations.

\section{Mechanism of Inhibition}

Results of the present study have shown that this extract inhibits the acid induced corrosion of steel by virtue of adsorption of its components onto the metal surface. The inhibition process is a function of the metal, inhibitor concentration, and temperature as well as inhibitor adsorption abilities which is so much dependent on the number of adsorption sites. The mode of adsorption depends on the type of adsorption (physisorption and chemisorption) observed could be attributed to the fact that this extract contains many different chemical compounds which some can adsorbed chemically and others adsorbed physically. This observation may be attributed to the fact that adsorbed organic molecules can influence the behavior of electrochemical reactions involved in corrosion processes in several ways. 

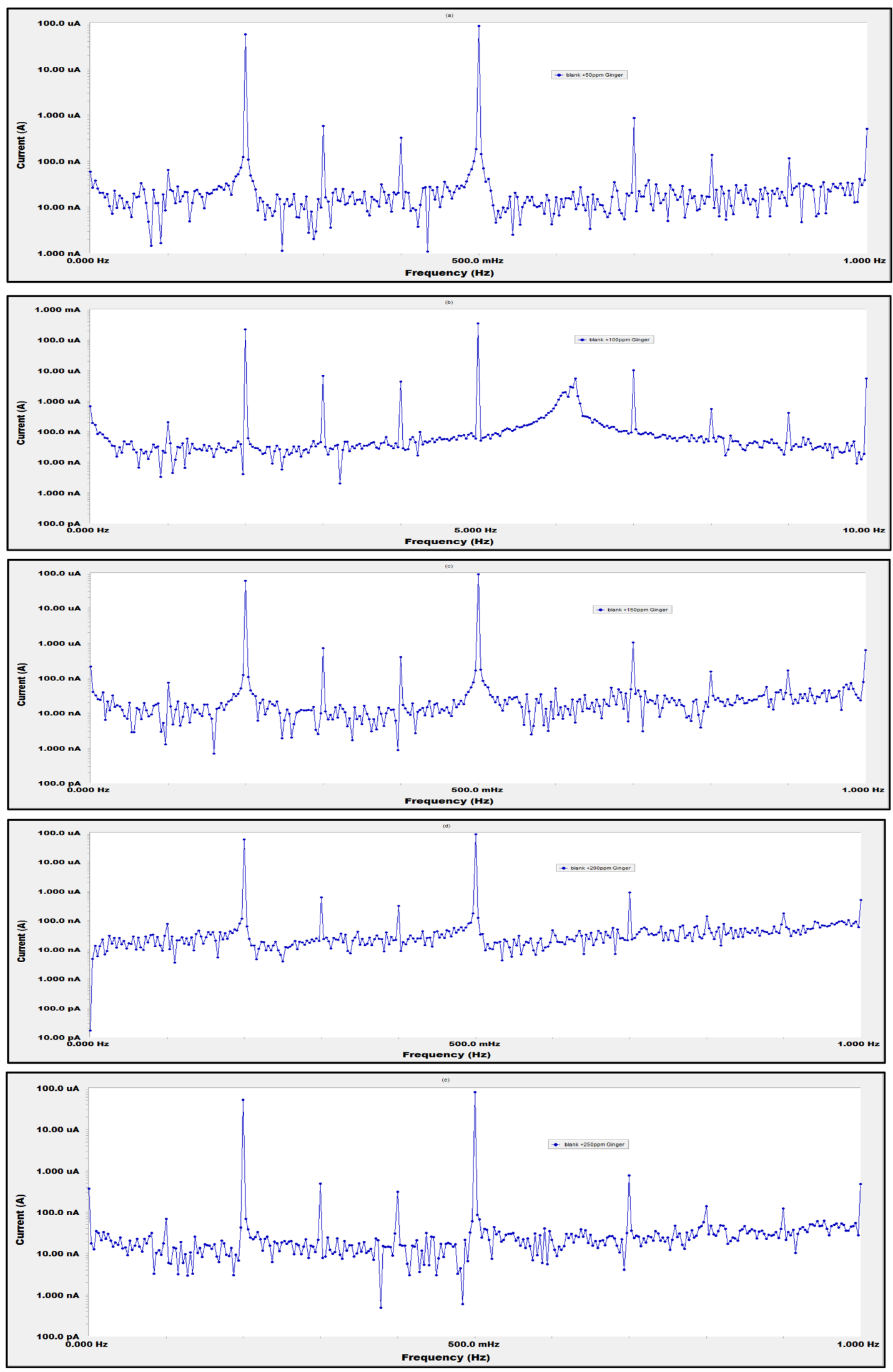

Fig. 5. Intermodulation spectrum for steel in $3.5 \% \mathrm{NaCl}+16 \mathrm{ppm} \mathrm{Na}_{2} \mathrm{~S}$ with various concentrations of ginger at $25^{\circ} \mathrm{C}$. 
Table 4. Electrochemical Kinetic parameters obtained by EFM technique for steel in $3.5 \% \mathrm{NaCl}+16 \mathrm{ppm} \mathrm{Na}_{2} \mathrm{~S}$ alone and with different concentrations of ginger at $25^{\circ} \mathrm{C}$

\begin{tabular}{ccccccccc}
\hline Conc., $\mathrm{ppm}$ & $i_{\text {corr }}, \mu \mathrm{A} \mathrm{cm}^{-2}$ & $\beta_{a}, \mathrm{mV} \mathrm{dec}^{-1}$ & $\beta_{c}, \mathrm{mV} \mathrm{dec}^{-1}$ & CF-2 & CF-3 & C.R, $\mathrm{mmy}^{-1}$ & $\theta$ & \% I \\
\hline blank & 13540 & 278.0 & 240.6 & 1.85 & 2.85 & 140.31 & - & - \\
50 & 7447 & 272.3 & 237.16 & 1.68 & 2.74 & 77.17 & 0.450 & 45.0 \\
100 & 4766 & 267.42 & 232.41 & 1.69 & 2.70 & 49.38 & 0.648 & 64.8 \\
150 & 4062 & 264.31 & 228.31 & 1.72 & 2.82 & 42.10 & 0.700 & 70.0 \\
200 & 3250 & 257.41 & 220.62 & 1.84 & 2.90 & 33.68 & 0.760 & 76.0 \\
250 & 1950 & 250.81 & 218.41 & 1.86 & 2.93 & 20.21 & 0.856 & 85.6 \\
\hline
\end{tabular}

Table 5. The results obtained from the plate counter for bacterial agriculture

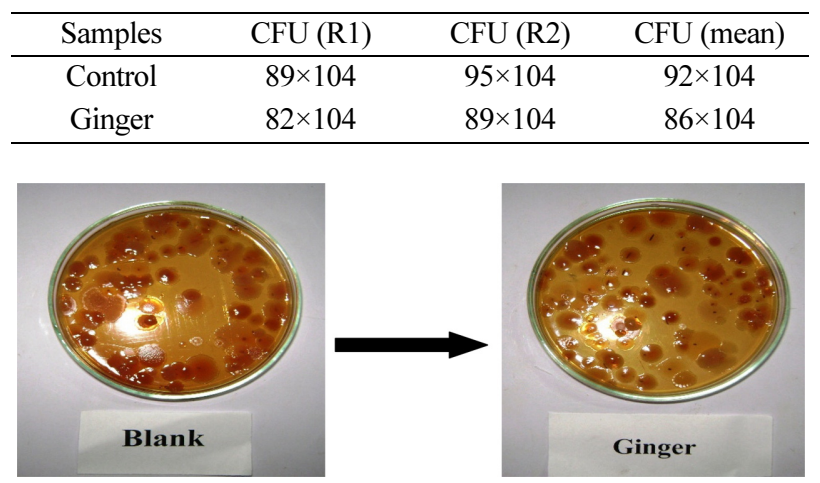

Fig. 6. Bacterial agriculture in the absence and presence of plant extract inhibitor.

The action of organic inhibitors depends on the type of interactions between the substance and the metallic surface. The interactions can bring about a change either in electrochemical mechanism or in the surface available for the processs. ${ }^{23}$ Also, the inhibition of steel by these extracts may be due to synergistic interactions of its phytochemicals constituents.

\section{CONCLUSION}

(1) Ginger extract acts as an inhibitor for corrosion of steel in sulfide polluted salt water.

(2) The inhibition efficiency increases with increase in the concentration of the inhibitor.

(3) The inhibition is due to the adsorption of the inhibitor molecule on the metal surface by charge transfer or by the diffusion of the inhibitor molecules.

(4) The adsorption of these compounds on the metal surface follows Temkin adsorption isotherm.

(5) This inhibitor has no biological effect on the activity of Escherichia Coli, and can be applied safely on waste water treatment plants.

Acknowledgments. The publication cost of this article was supported by the Korean Chemical Society. And the publication cost of this paper was supported by the Korean Chemical Society.

\section{REFERENCES}

1. El-Etre, A. Y. J. Colloid Interface Sci. 2007, 314, 578.

2. El-Etre, A. Y. Appl. Surf. Sci. 2006, 252, 8521.

3. Benabdellah, M.; Benkaddour, M.; Hammouti, B.; Bendahhou, M.; Aouniti, A. Appl. Surf. Sci. 2006, 252, 6212.

4. Chaieb, E.; Bouyanzer, A.; Hammouti, B.; Benkaddour, M. Appl. Surf. Sci. 2005, 246, 199.

5. Müller, B. Corros. Sci. 2002, 44, 1583.

6. Li, Y.; Zhao, P.; Liang, Q. Hou, B. Appl. Surf. Sci. 2005, 252, 1245.

7. El-Etre, A. Y.; Abdallah, M.; El-Tantawy, Z. E. Corros. Sci. 2005, 47, 385.

8. Bouyanzer, Hammouti, B.; Majidi, L. Mater. Lett. 2006, 60, 2840.

9. El-Etre, A. Y. Corros. Sci. 2003, 45, 2485.

10. Ammar, I. A.; Darwish, S. Corros. Sci. 1967, 7, 679.

11. Fisher, H. Ann. Univ. Ferrera. Sez. 1960, 3 (Suppl. 3), 1.

12. Stupnisek-Lisac, E.; Gazivoda A.; Madzarac, M. J. Electrochim. Acta 2002, 47, 4189.

13. Szklarska-Smiaiowska, Z. Electrochemical and Optical Techniques for the Study of Metallic Corrosion; Kluwer Academic: Netherlands, 1991, p 545.

14. Khamis, E. Corrosion 1990, 46, 476.

15. Ramachandran, S.; Tsai, M.; Blanco, M.; Chen, H.; Tang, W. A. Langmuir 1996, 12, 6419.

16. Oguzie, E. E. Corros. Sci. 2007, 49, 1527.

17. Larabi, L.; Benali, O.; M.Mekelleche, S.; Harek, Y.; J. Appl. Surf. Sci. 2006, 253, 1371.

18. Lagrenee, M.; Mernari, B.; Bouanis, B.; Traisnel M.; Bentiss, F.; Corros. Sci. 2002, 44, 573.

19. Bessone, J.; Mayer, C.; Tuttner, K.; Lorenz, W. J. Electrochim. Acta 1983, 28, 171.

20. Epelboin, I.; Keddam M.; Takenouti, H. J. Appl. Electrochem. 1972, 2, 71.

21. Khaled, K. F. Electrochim. Acta 2008, 53, 3484.

22. Khamis, E.; Bellucci, F.; Latahision, R. M.; El-Ashry E. Sh. Corrosion 1991, 47(9), 667.

23. Abdel-Rehim, S. S.; Khaled, K. F.; Abd-Elshafi, N. S. Electrochim. Acta 2006, 51(16), 3269. 